\title{
Novel Notions of the Mechanisms of Action of Doxorubicin and Ozone on Malignant Hepatic Cells
}

DOI: $10.17691 / \mathrm{stm} 2017.9 .2 .18$
Received December 22, 2016

A.V. Alyasova, MD, DSc, Professor, Department of Oncology ${ }^{1}$;

I.G. Terentiev, MD, DSc, Professor, Head of the Department of Oncology, Vice-Rector on Scientific Work';

S.N. Tsybusov, MD, DSc, Professor, Head of the Department of Operative Surgery and Topographic Anatomy Vice-Rector for Academic Affairs";

M.V. Vedunova, DSc, Director of the Institute of Biology and Biomedicine;

T.A. Mishchenko, PhD, Senior Researcher, Central Research Laboratory';

K.A. Shakhova, PhD, Tutor, Department of Clinical Laboratory Diagnosis ${ }^{1}$;

K.N. Kontorshchikova, DSc, Professor, Head of the Department of Clinical Laboratory Diagnosis ${ }^{1}$

${ }^{1}$ Nizhny Novgorod State Medical Academy, 10/1 Minin and Pozharsky Square, Nizhny Novgorod, 603005,

Russian Federation;

${ }^{2}$ Lobachevsky State University of Nizhni Novgorod, 23 Prospect Gagarina, Nizhny Novgorod, 603950,

Russian Federation

The aim of the investigation was to verify the similarity of triggering mechanisms of ozone and doxorubicin action on the culture of human malignant hepatic cells.

Materials and Methods. The effect of chemotherapeutic agent doxorubicin, ozone and their combination on malignant hepatic cells (SK-HEP-1) has been studied experimentally on the culture medium.

Results. A similar increase of free radical oxidation has been established to occur under the action of ozone and doxorubicin both separately and in combination. Their introduction in all variants elevated also the content of caspase- 3 enzyme, and the levels of caspase-3 were substantially higher than in doxorubicin introduction. The results obtained show new mechanisms of ozone and doxorubicin effect on the viability and morphological alterations in malignant hepatic cells: activation of free radical oxidation induces necrotic and apoptotic changes in these cells via the increase of caspase quantity.

Key words: malignant hepatic cells; ozone; doxorubicin; caspase.

The effect of doxorubicin chemopreparation, ozone and their combination has been investigated in previous experiments [1] on laboratory animals (rats), who were transplanted breast cancer strains. The results obtained have demonstrated that the combined effect of low therapeutic ozone concentrations in the ozonized physiological solution and doxorubicin exerted the most marked destructive effect on the tumor. Application of ozonized physiological solution has potentiated antitumor activity of doxorubicin, which manifested itself in a pronounced inhibition of mitotic activity of tumor cells and reduction of their viable element number. Examination of IR spectra of tumor tissues, liver, lungs, and brains of tumor-bearing animals [2] confirmed a higher therapeutic effect of the combined action of doxorubicin and ozone.

Experiments on the culture of normal hepatic cell Chang liver and malignant human liver cells SK-HEP-1 continued these investigations [3]. Introduction of ozone into the culture medium was found to induce a marked cytostatic effect on the cell viability similar to that of doxorubicin, which was confirmed by morphological data on irreversible changes in the structure of the cellular elements of necrotic or apoptotic origin. In spite of the evidential material on the viability and pathomorphosis of malignant cells exposed to the analyzed factors, the intracellular mechanism of triggering cell death remains unclear. Doxorubicin is known to be a cytostatic of anthracycline line with antimitotic and antiproliferative action. The mechanism of the preparation action is explained by its reaction with DNA, formation of free radicals and direct effect on the cell membranes with inhibition of nucleic acid synthesis. In regard to activation of free-radical reactions, the effect of doxorubicin may be compared with the action of ozone as a strong oxidizing agent regulating pro- and antioxidative balance [4-6].

The other possible mechanism initiating cell death is an enzymatic way with the participation of caspases. Caspases are a family of aspartate-specific cysteine proteases, they are present in all cells, interaction of these proteases with oligomeric receptors results in their activation. Active caspases can trigger proteolytic

For contacts: Klavdia N. Kontorshchikova, e-mail: kontclin@mail.ru 
cascade cleaving proteins necessary for survival. The final result of the signaling pathway is activation of controlled cell death, apoptosis. Caspases involved in apoptosis are divided into initiator and effector. One of the effector caspases is caspase-3 cleaving the substrate on the carboxyl terminus following aspartate residues. Inhibition of apoptotic process can lead to the development of oncological diseases [7].

Based on the results of our investigations and the literature data, comparability of triggering mechanisms of ozone and doxorubicin action inside the cells can be supposed.

The aim of the investigation was to verify experimentally the similarity of triggering mechanisms of ozone and doxorubicin action on the culture of malignant human hepatic cells.

Materials and Methods. Experiments were carried out on cultured SK-HEP-1 cells of human hepatic adenocarcinoma having epithelium-like morphology. Cells were cultivated in Minimum Essential Medium Eagle (MEM) with Earle's salts (PanEco, Russia), with addition of $10 \%$ fetal bovine serum (PanEco, Russia) and $1 \%$ of non-essential amino acids (PanEco, Russia), at optimal density of $(2.0-4.0) \cdot 10^{6} \mathrm{cells} / \mathrm{cm}^{2}$.

The cell viability was maintained in $\mathrm{CO}_{2}$-incubator with $5 \% \mathrm{CO}_{2}$ content. After $3-5$ passages, the cells were placed on 48 - or 6-well plates. Once a $60 \%$ monolayer was reached, the culture medium was replaced by the test media. The first medium was prepared by adding $0.004 \mathrm{mg}$ doxorubicin; the second one by introducing $150 \mathrm{ml}$ oxygen; the third medium was prepared by introducing $150 \mathrm{ml}$ of ozone-oxygen mixture at ozone concentration of $25 \mathrm{mg} / \mathrm{L}$, the fourth medium by introducing $150 \mathrm{ml}$ oxygen and $0.004 \mathrm{mg}$ doxorubicin; and the fifth medium by introducing $150 \mathrm{ml}$ of ozone-oxygen mixture and $0.004 \mathrm{mg}$ doxorubicin. The doses of doxorubicin and ozone were determined during experimental assessment of malignant tumor pathomorphosis on animals [1].

The culture medium was ozonized with ozone-oxygen gas mixture supplied at $1 \mathrm{~L} / \mathrm{min}$ rate for $5 \mathrm{~min}$ from ozone generator (Kwazar, Russia). After 48 h of cultivation, the cell medium was removed, the cells were washed with phosphate buffered saline $(\mathrm{pH}=7.4)$ and a mixture of $250 \mathrm{ml}$ Versen (0.02\%):trypsin (0.25\%) (3:1). After $10 \mathrm{~min}$ of incubation in $\mathrm{CO}_{2}$-incubator, the cells were pipetted, and $250 \mathrm{ml}$ of $8 \%$ formaldehyde were added to each well. Then the number of cells was calculated using automated Scepter analyzer (Millipore, UK).

To analyze the activity of free radical oxidation, the cell suspension was washed three times with buffered physiological solution and frozen at $-20^{\circ}$. Before the investigation, it was defrosted and homogenized. The intensity of free radical oxidation was assessed by the parameters of iron- and hydrogen peroxideinduced chemiluminescence using BHL-07 device (Nizhny Novgorod, Russia): Imax is a maximal luminescence intensity, $S$ is chemiluminescence light sum for $30 \mathrm{~s}$ [8]. The content of peroxide lipid products, primary conjugated dienes (CD), conjugated trienes (CT), final Schiff bases (SB) were determined in heptane:isopropanol fractions using Volchegorsky's method [9]. The amount of caspase-3 enzyme was evaluated by immunoenzyme Human Caspase-3 Instant ELISA assay (ThermoFisher Scientific, USA), and calculated per number of cells in $\mathrm{ml}$ (cell content $\left.5 \cdot 10^{6} / \mathrm{ml}\right)$.

The results obtained were processed using Biostat program package and were presented as $M \pm \sigma$, where $M$ is mean and $\sigma$ is standard deviation. Significance of mean differences was determined by a Student's t-test. Differences were considered significant at $p<0.05$.

Results. Introduction of doxorubicin in the medium for culturing SK-HEP-1 human hepatocarcinoma cells (Table 1) was accompanied by statistically significant 2.7-fold increase of Imax and 2.5-fold increase of S, which signified the activation of free radical reactions by the cytostatic. Ozonation of the culture medium in a way similar to that of doxorubicin activated free radical reactions and displayed itself as 2.6-fold increase of Imax and 2.5-fold increase of S. Combined introduction of doxorubicin and oxygen as well as doxorubicin and ozone in the culture medium did not decreased statistically significantly the high levels of Imax and S characteristic for the medium with doxorubicin, and amounted to 1.8 and 2.2 times for Imax and 2.1 and 2.5 times for $S$, respectively.

Thus, the supposition that one of the mechanisms causing decrease of viability of malignant hepatic cells and their morphological alterations [3] are free radical reactions initiated by the oxidizer and toxic doxorubicin compound has been confirmed. Data on studying the levels of lipid peroxidation products served as an additional proof of the proposition (Table 2).

The most marked changes in the values characterizing the activity of lipid peroxidation in the culture of malignant cells were observed in the cells being in the medium with doxorubicin. CD levels in these cells increased almost 4 times, CT -4.5 times,

Ta ble 1

Chemiluminescence indices of homogenate of malignant human hepatic SK-HEP-1 cells

\begin{tabular}{lcc}
\hline \multicolumn{1}{c}{ Culture medium } & \multicolumn{1}{c}{ Imax } & S for $30 \mathrm{~s}(\mathrm{mV})$ \\
\hline $\begin{array}{l}\text { Intact cells on the standard } \\
\text { medium }\end{array}$ & $128.6 \pm 11.7$ & $338.7 \pm 21.4$ \\
\hline Doxorubicin & $336.4 \pm 21.8^{*}$ & $867.6 \pm 49.3^{*}$ \\
\hline Oxygen & $143.6 \pm 26.8$ & $386.9 \pm 51.1$ \\
\hline Ozone & $327.4 \pm 43.4^{*}$ & $843.8 \pm 62.1^{*}$ \\
\hline Doxorubicin + oxygen & $245.3 \pm 55.2^{*}$ & $676.8 \pm 56.1^{*}$ \\
\hline Doxorubicin + ozone & $289.6 \pm 23.9^{*}$ & $683.1 \pm 61.2^{*}$ \\
\hline
\end{tabular}

* Differences are statistically significant compared to the intact cells $(p \leqslant 0.05)$. 
Table 2

Content of lipid peroxidation products in malignant human hepatic SK-HEP-1 cells (relative units)

\begin{tabular}{lcccccc|}
\hline $\begin{array}{c}\text { Products of lipid } \\
\text { peroxidation }\end{array}$ & Intact & Oxygen & Ozone & Doxorubicin & $\begin{array}{c}\text { Oxygen }+ \\
\text { doxorubicin }\end{array}$ & $\begin{array}{c}\text { Ozone }+ \\
\text { doxorubicin }\end{array}$ \\
\hline $\mathrm{CD}$ & $0.06 \pm 0.005$ & $0.05 \pm 0.001$ & $0.71 \pm 0.12^{*}$ & $0.22 \pm 0.08^{*}$ & $0.21 \pm 0.040^{*}$ & $0.37 \pm 0.11^{*}$ \\
\hline $\mathrm{CT}$ & $0.03 \pm 0.001$ & $0.02 \pm 0.0025$ & $0.41 \pm 0.11^{*}$ & $0.14 \pm 0.011^{*}$ & $0.13 \pm 0.012^{*}$ & $0.15 \pm 0.09^{*}$ \\
\hline $\mathrm{SB}$ & $4.43 \pm 1.71$ & $2.36 \pm 0.49$ & $25.78 \pm 3.05^{*}$ & $33.0 \pm 4.20^{*}$ & $15.53 \pm 3.09^{*}$ & $29.73 \pm 3.11^{*}$ \\
\hline $\mathrm{SB} /(\mathrm{CD}+\mathrm{CT})$ & $49.0 \pm 9.1$ & $33.7 \pm 10.07$ & $23.0 \pm 8.1$ & $91.2 \pm 11.4^{*}$ & $46.0 \pm 13.2$ & $58.3 \pm 8.9^{*}$ \\
\hline
\end{tabular}

* Differences are statistically significant compared to the intact cells $(p \leqslant 0.05)$.

$\mathrm{SB}-4$ times. $\mathrm{SB} /(\mathrm{CD}+\mathrm{CT})$ coefficient representing a quantitative ratio of the end products to primary ones, increased 2 times, which was the evidence of the reaction shift to the direction of hard toxic SB accumulation, causing damage to cellular membranes. Ozonation of the culture medium statistically significantly increased the content of CD 11.8 times, CT 13.3 times, SB 4.5 times, the $\mathrm{SB} /(\mathrm{CD}+\mathrm{CT})$ coefficient decreased 2 times in comparison with the initial level, which spoke of the predominance of initial products of lipid peroxidation and, therefore, of the actively continuing process at the initiation stages. Combined introduction of doxorubicin with oxygen and doxorubicin with ozone did not cause differences in the levels of $C D$ and $C T$, whereas more significant differences of $\mathrm{SB}$ and $\mathrm{SB} /(\mathrm{CD}+\mathrm{CT})$ coefficient levels (See Table 2) were observed in combination of doxorubicin and ozone. High levels of SB and SB/ $(C D+C T)$ coefficient signified the accumulation of end products of SB lipid peroxidation, which can damage the cells, and affect the parameters of cell viability and morphology.

Apart from the damaging effect of free radical oxidation on intracellular structures, destructive action of enzymes causing apoptosis cannot be excluded. One of such enzymes is caspase- 3 . The content of this enzyme in the homogenate of the cells contained on the cultural media, in which doxorubicin, ozone, oxygen, and their combination were introduced, was evaluated in our study.

The highest concentration of caspase- 3 was noted, when malignant cells were exposed to doxorubicin $(4.76 \pm 0.06 \mathrm{pg} / \mathrm{ml})$, it exceeded 30 times the content of the enzyme in the cells of the intact series $(<0.16 \mathrm{pg} / \mathrm{ml})$. This fact was a confirmation of a high apoptotic activity of doxorubicin detected during morphological examinations. Ozonation of the culture medium increased 11 times the amount of caspase $(1.82 \pm 0.01 \mathrm{pg} / \mathrm{ml})$. When the medium for cell culturing was replaced by the medium containing doxorubicin and ozone, the amount of caspase increased 13 times $(2.04 \pm 0.03 \mathrm{pg} / \mathrm{ml})$, and when replaced by the medium containing doxorubicin and oxygen, it increased 16.6 times $(2.67 \pm 0.02 \mathrm{pg} / \mathrm{ml})$.

The obtained results show that the main cause of triggering apoptotic process in our experiments with malignant cells contained in the media exposed to doxorubicin or oxidizers, is increase of caspase-3 levels. In its turn, increase of caspase concentration is most likely to be a consequence of activation of free radical oxidation under the action of both doxorubicin and ozone.

Conclusion. Introduction of doxorubicin or ozone in the culture medium activates the processes of free radical oxidation in the hepatic malignant cells, which is accompanied by the increase of lipoperoxidation products. Their introduction increases the concentration of caspase-3 enzyme in isolated and combined action, the increase of caspase- 3 amount being more significant with the use of doxorubicin. Activation of free radical oxidation causes both necrotic and apoptotic alterations in the cells of hepatic culture due to the increase of caspase amount.

Study Funding. The work was not supported by any sources.

Conflicts of interest. The authors have no conflicts of interest to disclose.

\section{References}

1. Alyasova A.V., Kontorshickova K.N., Terentiev I.G., Ivanova I.P., Kuznetsov S.S., Sazanov A.I. Influence of the ozonized physiologic salt solution low therapeutic concentrations on a tumor therapeutic pathomorphosis in experiment. Sovremennye tehnologii v medicine 2010; 4: 27-32.

2. Krasnikova O.V., Gordetsov A.S., Kontorstchikova K.N., Krylov V.N., Sazanov A.I. The change of infrared spectrum parameters of biological tissues of animals-carriers of tumours against the background of combined administration of doxorubicin and ozone. Sovremennye tehnologii $v$ medicine 2011; 3: 83-87.

3. Alyasova A.V., Vedunova M.V., Mishchenko T.A., Terentyev I.G., Tsybusov S.N., Kontorshchikova K.N. Effect of ozone and doxorubicin on the viability and morphology of malignant hepatic cells. Sovremennye tehnologii $v$ medicine 2016; 8(2): 84-89, http://dx.doi.org/10.17691/stm2016.8.2.12.

4. Kontorshchikova K.N. Perekisnoe okislenie lipidov pri korrektsii gipoksicheskikh narusheniy fiziko-khimicheskimi faktorami. Avtoref. dis. ... dokt. biol. nauk [Lipid peroxidation during the correction of hypoxic disorders by physico-chemical factors. DSc Thesis]. Nizhny Novgorod; 1992.

5. Maslennikov O.V., Kontorshchikova K.N., Shakhov B.E. 
Rukovodstvo po ozonoterapii [Guidelines on ozone therapy]. Nizhny Novgorod: Izdatel'stvo “Istok"; 2015; 345 p.

6. Kontorshchikova

K.N.,

Peretyagin

S.P.

Zakonomernost' formirovaniya adaptatsionnykh mekhanizmov organizmov mlekopitayushchikh pri sistemnom vozdeystvii nizkimi terapevticheskimi dozami ozona [Principles governing formation of adaptive mechanisms of mammal organisms under systemic exposure to low therapeutic ozone doses]. Diplom na otkrytie No.309 [Diploma for Discovery 309]. 2006.

7. Sarvilina I.V., Karkishchenko V.N., Gorshkova Yu.V. Mezhdistsiplinarnye issledovaniya $v$ meditsine [Interdisciplinary investigations in medicine]. Moscow: Tekhnosfera; 2007; p. $139-145$.
8. Kuz'mina E.I., Nelyubin A.S., Shchennikova M.K. Primenenie indutsirovannoy khemilyuminestsentsii dlya otsenok svobodnoradikal'nykh reaktsiy $v$ biologicheskikh substratakh. V kn.: Mezhvuzovskiy sbornik biokhimii i biofiziki mikroorganizmov [Application of induced chemiluminescency for assessing free radical reactions in biological substrates. In: Intercollegiate book on biochemistry and biophysics of microorganisms]. Gor'kiy; 1983; p. 179-183.

9. Volchegorskiy I.A., Nalimov A.G., Yarovinskiy B.G., Lifshits R.I. Comparison of various approaches to determination of LPO products in heptane-isopropanol extracts of blood. Voprosy meditsinskoy khimii 1989; 1: $127-131$. 